Atmos. Chem. Phys. Discuss., 9, 21915-21940, 2009 www.atmos-chem-phys-discuss.net/9/21915/2009/ (C) Author(s) 2009. This work is distributed under the Creative Commons Attribution 3.0 License.

\title{
Source apportionment of mercury in dust fallout at urban residential area of Central India
}

\section{S. Pervez ${ }^{1}$, G. Balakrishna ${ }^{1}$, and S. Tiwari ${ }^{2}$}

${ }^{1}$ School of Studies in Chemistry, Pt. Ravishankar Shukla University, Raipur-492010, India

${ }^{2}$ Indian Institute of Tropical Meteorology Pune Zonal Laboratory, New Delhi, India

Received: 30 September 2009 - Accepted: 1 October 2009 - Published: 19 October 2009

Correspondence to: S. Pervez (shamshp@yahoo.co.in)

Published by Copernicus Publications on behalf of the European Geosciences Union.

\section{ACPD}

9, 21915-21940, 2009

Source

apportionment of

mercury in dust

fallout

S. Pervez et al.

Title Page

Abstract

Introduction

Conclusions

References

Tables

Figures

14

$\rightarrow$

4

Back 


\section{Abstract}

The components and quantities of atmospheric dust fallout have been reported to be the pollution indicator of large urban areas. The multiplicity and complexity of sources of atmospheric dusts in urban regions (e.g. industrial complexes composed of a vari5 ety of industrial processes, automobiles, construction activities etc.) has put forward the need of source apportionment of these sources indicating their contribution to specific environmental receptor. The study presented here is focused on investigation of source contribution estimates of Mercury in urban dust fallout in an urban-industrial area, Raipur, India. Source-receptor based representative sampling plan using longitudinal study design has been adopted. Six sampling sites have been identified on the basis of land use for development plan of anthropogenic activities and factors related to the transportation and dispersion pattern of atmospheric dusts. 24 samples of dust fallout has been collected from each site (one in each month) and subjected to chemical analysis of selected chemical constituents known as markers of selected major dust emitting sources (Steel making average, Road traffic-borne dusts, construction activities, Auto mobile exhaust, and soils). Chemical composition of dust measured at sites marked for identified sources alongwith SPECIATE of USEPA has been used for the preparation of source profiles. Three classified residential receptors (ambient-outdoor, house-indoors and local street-outdoors) have been chosen for development of receptor compositional profiles. Source apportionment has been done using Chemical Mass Balance (CMB 8). Good fit parameters and relative source contribution has been analysed and documented. Dust fallout and respective mercury levels were found tobe higher compared to prescribed standards. Variation in relative contribution of selected sources from site to site within the study area has been occurred. Dominance of local line and area sources (road-traffic and construction borne dusts) on mercury levels measured at selected residential receptors compared to stationary industrial sources has been observed. Road-traffic has shown highest contribution of dust and mercury in house-indoors, while in case of ambient-outdoor the receptor has shown different

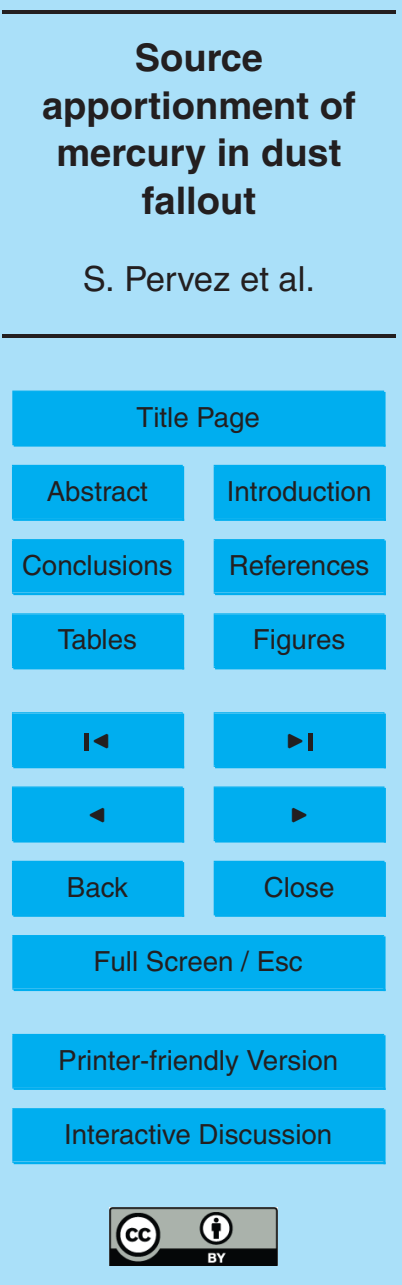


higher susceptibility of identified sources for dust and mercury. The results of CMB output and regression data of source-receptor dust matrices have shown comparable pattern.

\section{Introduction}

5 Mercury $(\mathrm{Hg})$ is a persistent, bio-accumulative toxic pollutant. Once $\mathrm{Hg}$ is released into the environment, it can be converted to the organic form, methyl mercury ( $\mathrm{MeHg}$ ) and then bio-accumulate in organisms within the food chain, such as fish, posing a consumption risk to wildlife and humans. Mercury is emitted into the atmosphere through both natural and anthropogenic processes with $50-75 \%$ of global emissions attributed to anthropogenic sources (Nriagu et al., 1990, EPMAP 1994). The major sources of mercury to the atmosphere include fossil fuel combustion, waste incineration, ironsteel production, coke and lime production, hazardous waste recycling, non-ferrous metal smelting, petroleum refining, and mercury cell chlor-alkali plants (Keelar et al., 1995; Landis et al., 2004). Gerald and Keeler (2006) has reported that the annual wet

15 deposition of mercury for 2003 and 2004 were 14.0 and $13.5 \mathrm{ng} \mathrm{L}^{-1}$ and total annual mercury wet deposition was 13.5 and $19.7 \mu \mathrm{gL}^{-1}$. Sharma and Parvez (2005) has observed selected toxic elements ( $\mathrm{As}, \mathrm{Pb}, \mathrm{Mn}, \mathrm{Hg}$ and $\mathrm{Cd}$ ) were determined in human breast milk and blood samples obtained from 120 subjects related to an integrated steel plant environment located in central India. The mechanisms of $\mathrm{Hg}$ transport dur20 ing hydrological events are poorly understood and yet may influence $\mathrm{Hg}$ bioavailability and exposure to aquatic biota (Joseph et al., 2008).

Increasing severity of dispersion and fallout of fugitive dusts in urban areas of India has shown spontaneous linkage with higher degree of health disorders especially bronchial ailments (Saxena et al., 2008; Quraishi and Pandey, 1995; Sharma and Pervez, 2005; Sharma and Pervez, 2003; Bohm and Saldiva, 2000; Goel and Trivedi, 1998). Due to higher settling tendency of bigger particles of dust fallout fraction near emission sources on a regional scale, researchers have made classification of its re-

\section{Source \\ apportionment of \\ mercury in dust fallout}

S. Pervez et al.

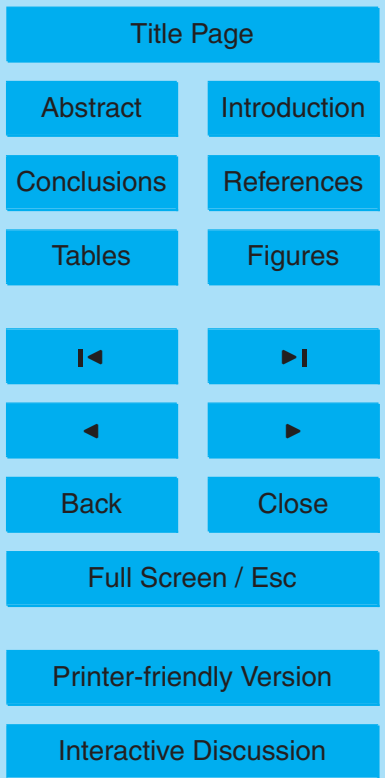


ception pattern as ambient-outdoor, street-outdoor and indoors dust fallout (Dubey and Pervez, 2008; USEPA, 2003; Quraishi and Pandey, 1993; Sharma and Pervez, 2004; Gadkari and Pervez, 2007). Due to presence of a variety of point, line and area sources of dusts emission, an non-uniform distribution of dusts in various environmental media 5 has been reported earlier (Sharma and Pervez, 2004). (Sartor and Boyd, 1972; Pitt and Amy, 1973; Pitt, 1979; Mustard et al., 1985; Schroder and Hedley, 1986; Schroder et. al., 1987; ISWS, 2003).

Adachi and Tainosho (2004) have characterize the street dusts to investigate $\mathrm{Zn}$ as tire dust indicator in Japan using reference work done in the field of chemical apportion10 ment of road-traffic settleable dusts earlier (Smolders and Degryse, 2002; Davis et al., 2001, Rogge et al., 1993). Atmospheric deposition of vanadium, lead, chromium, copper, zinc and nickel has been described earlier (Dundar, 2006; Dundar and Pala, 2003; Dundar and Altundag, 2002; Dundar and Deryaoglu, 2005; Barceloux, 1999; Turkoglu et al., 2003; Tuzen, 2003; Arslan, 2001). Large size particles of dusts fallout in urban 15 regions has been reported to be the major cause of prevalence of asthma (occur at upper nasal area) compared to association of fine particulates with inner respiratory disorders (Sax and Richard, 1984; Roosli, 2000; Wieringa et al., 1997; USEPA, 2003).

The presented work has been focused on source apportionment of dust fallout in selected classified urban receptor of Raipur City, India which located in global scale of: $21^{\circ} 14^{\prime} 22.7^{\prime \prime} \mathrm{N}$ latitude and $81^{\circ} 38^{\prime} 30.1^{\prime \prime} \mathrm{E}$ longitudes. Regression analysis between various longitudinal measurements of selected and defined deposit regions has been utilized to identify possible sources/routes of dust transport to a receptor region. Chemical mass balance (CMB8, USEPA) has been executed to investigate source contribution estimates of dust fallout in relation to source signature of mercury in a specific ambient-outdoor receptor located in a residential area.

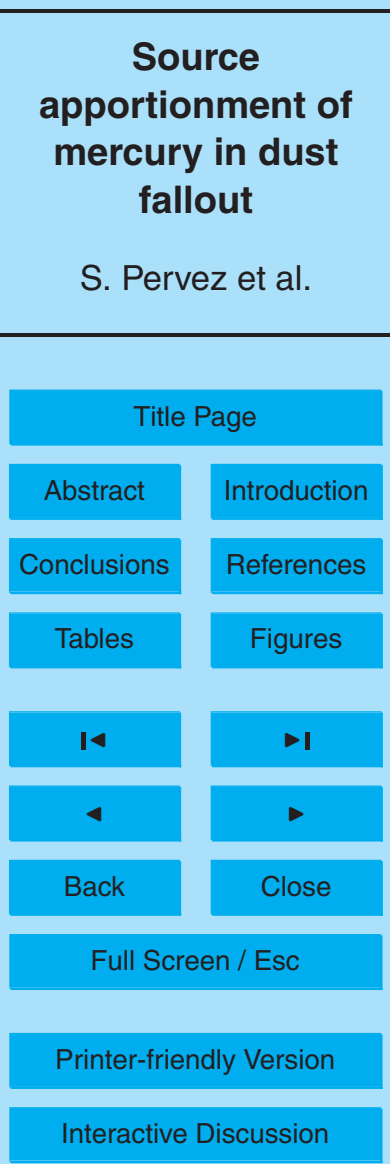




\section{Materials and method (study design, sampling plan and data analysis)}

\subsection{Study design}

The study was undertaken in an urban area. The goal of the study is to evaluate relative source contribution estimates of various routes of mercury in dust fallout in urban res5 idential environment. The objectives here are: (1) To measure and characterize dust fallout and mercury at identified sources (2) to analyze statistically, the relationship between dust fallout measurements of source-routes and residential-receptors and (3) to carryout apportionment of Mercury in dust fall at classified residential-receptors, taking identified atmospheric routes as possible sources using Chemical mass balance

10 Model (CMB8). A residential area (Birgaon) located in close proximity to a major industrial area (Siltara) has been selected for the study. Apart from two major industrial sources of dusts emission, local soils, paved road dusts and automobile exhaust emissions alongwith construction activities have also been identified to cluster of source profiles for source apportionment. The details of location of residential colony (receptor), major industrial complexes, wind rose and wind channels have been shown in Figs. 1-2.

\subsubsection{Sampling design}

A comprehensive study about source contribution estimates of major possible and observable sources of dusts emission to dust fallout of urban areas (residential, commercial and sensitive regions) was started from yr 2007. Source apportionment study of Mercury in dust fallout of a specific urban-residential region has been presented here. A non-probability based longitudinal stratified random sampling design in space-time frame work has been chosen to achieve the objectives (Gilbert, 1987; USEPA, 2003). Ambient-outdoor atmospheric level has been decided for measurement of dust fallout at identified sources of dust emissions. In case of residential-receptor, three most susceptible atmospheric levels have been chosen, namely ambient-outdoors, house-

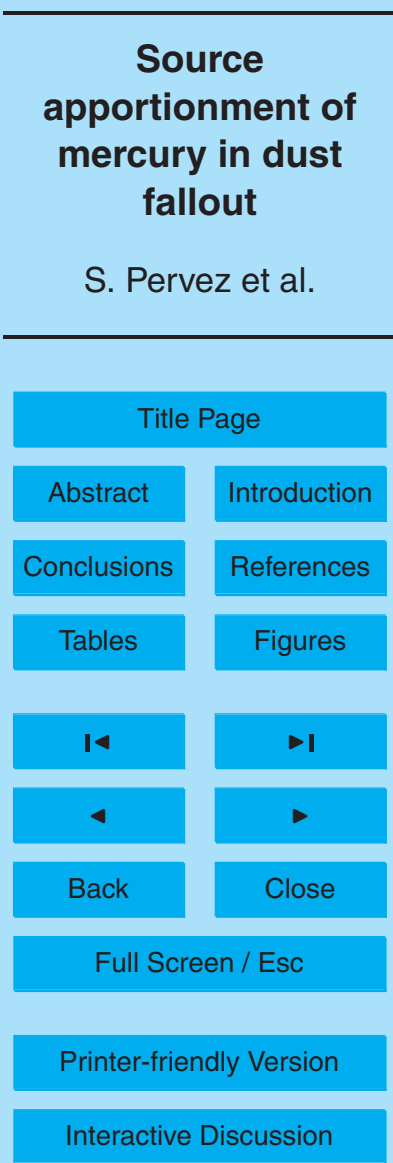

\section{9}


indoors and local street-outdoors (Table 1).

\subsubsection{Sampling method of Dust fallout}

Dust emission sources were identified using layout map, anthropogenic activity patterns and urban-industrial development plan of the study area. The identified sources

5 (Table 1) were classified in point, line and regional sources of dust emission (Goel and Trivedi, 1998). Dust collection Jars (Dimension: dia-23" ht-45") with standard specifications (Katz, 1977; Thakur and Deb, 1999) has been placed for a month at a height of $10 \mathrm{ft}$ (ambient-outdoor), at both source (S-1, S-2) and receptor sites, $5 \mathrm{ft}$ (local streetoutdoor) and $1 \mathrm{ft}$ (indoor-house) at receptor sites. Sampling at local-outdoor ( $5 \mathrm{ft}$ height)

10 has been chosen for measurement at construction activity site. In case of sampling at paved road source (S-3), sampler was installed at the height of $5 \mathrm{ft}$ at major cross road passing near to the residential colony. About a liter of double distilled water was placed in each Jar and a net sheet (size: 20 mesh) was placed on mouth of the Jars. Water soluble and insoluble fraction of dust fallout has been measured separately and by adding them, total dust fallout was measured. Five replicate measurements were done to minimize weighing error (Table 2).

As far as soil chemical profile (S-6) is concern, samples of soils $(1 \mathrm{~kg})$ have been collected from open land of residential colony. Soil samples were collected after removing surface soils upto $6 \mathrm{~cm}$ depth (Gadkari and Pervez, 2008). Black smoky dust emitted 20 and deposited in automobile exhaust silencers of diesel fuel based heavy duty trucks and petrol based cars have been collected and scum were mixed together for development of chemical profile of automobile source (S-4). Vehicles have been selected randomly which mostly passes through that road junction. About $5-10 \mathrm{~g}$ of exhaust emitted black smoky dust has been collected. Frequency of sampling was 24 (one in 25 each month) at each source-receptor site throughout the sampling period (February 2007 to January 2009).

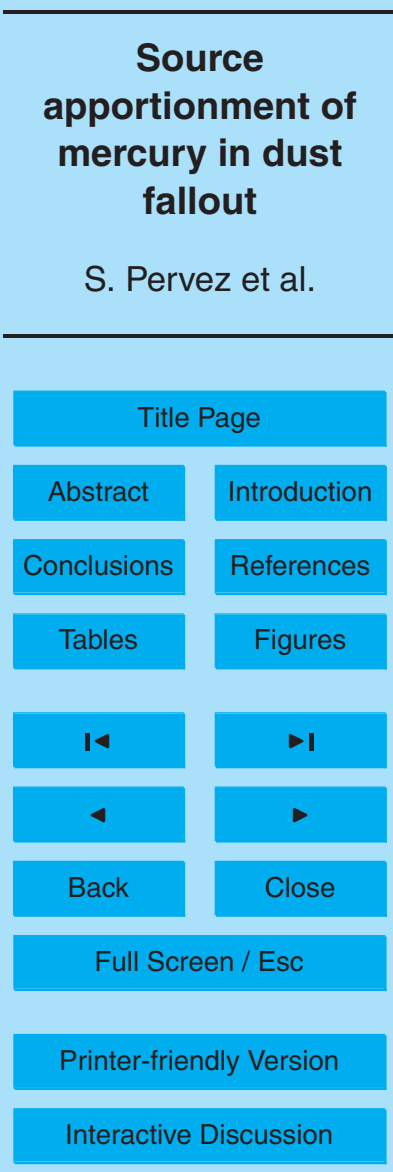




\subsection{Chemical analysis of dust fallout}

Dried samples of soils and automobile exhaust scum have been powdered using a milling machine. Powder and dust samples were digested in Teflon digestion bomb and nitric acid $\left(\mathrm{HNO}_{3}\right)$ and hydrogen peroxide $\left(\mathrm{H}_{2} \mathrm{O}_{2}\right)$ (3:1). Teflon bomb was then

5 kept in an electric oven at $110^{\circ} \mathrm{C}$ for $8 \mathrm{~h}$, cooled, and contents filtered in a volumetric flask and washed with dilute $\mathrm{HNO}_{3}$. Final volume of digested sample was made up to $25 \mathrm{ml}$ using distilled water. Digested samples and soluble fraction of dust fallout measured during field sampling were analyzed for total $\mathrm{Hg}$ content using inductive coupled plasma-atomic emission spectrophotometer (ICP-AES) (JOBIN-YVON HORIBA ICP

10 Spectrometer Version 3.0). An Argon gas (ionization energy, of $15.6 \mathrm{eV}$ ) was used as plasma. $\mathrm{Hg}$ analysis was carried out at a wavelength of $194.22 \mathrm{~nm}$ to avoid spectral and chemical interferences. Calibration of instrument was done using $\mathrm{HgCl}_{2}$ ( $\mathrm{AR}, \mathrm{Merck}$ ) of concentration range $0.001-0.1 \mathrm{ppm}$ (Montaser and Golightiy, 1987). Apart from mercury, 24 other chemical species known for indicator species of identified sources have 15 also been analyzed in all source-receptor dust matrices using ICP-AES by recommended procedure of analysis and data were utilized as necessary input for chemical mass balance modeling.

\subsection{Data analysis}

Measurement data of dust fallout and particulate mercury has been documented as geometrical mean and standard deviation of longitudinal measurements of each monitoring site and presented in Table 2. Regression analysis between annual mean of dust fallout measured at defined receptor site (local-outdoor, indoor and street of Birgaon residential region) and selected source sites (Siltara Industrial complex, Urla Industrial complex, paved road and construction sites) has been conducted and presented in 25 Fig. 3.

The source profile abundances (mass fraction of chemicals in the emissions from each source type) and the receptor concentrations, with appropriate uncertainty es-

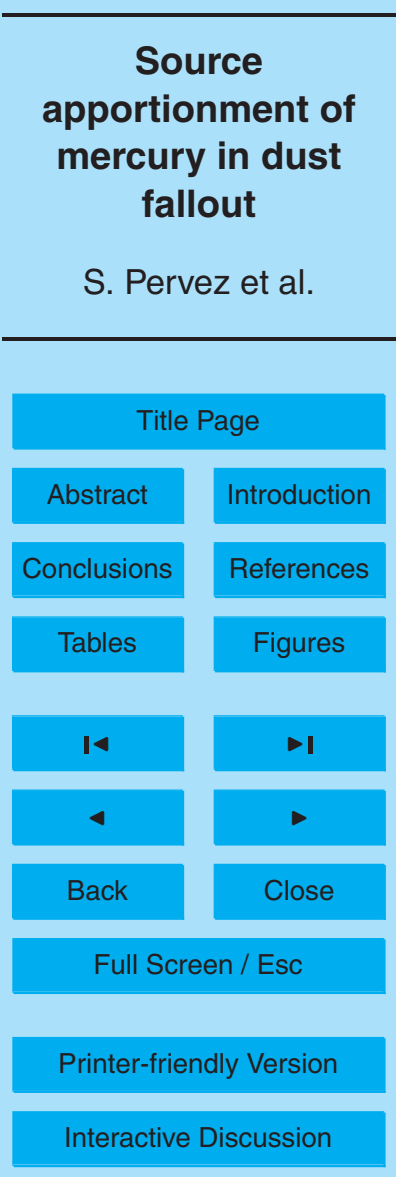

21921 
timates, serve as input data to the CMB model. The output consists of the amount contributed by each source type represented by a profile to the total mass and each chemical species. The CMB calculates values for the contributions from each source and the uncertainties of those values. The CMB is applicable to multi-species data 5 sets. The CMB modeling procedure requires: (1) Identification of the contributing source type; (2) selection of chemical species or other properties to be included in the calculation; (3) estimation of the fraction of each of the chemical species which is contained in each source type (source profile); (4) estimation of the uncertainty in both receptor concentrations and source profiles; and (5) solution of the chemical mass

10 balance equations. The CMB is implicit in all factor analysis and multiple linear regression models that intend to quantitatively estimate source contributions. The chemical mass balance consists of a least squares solution to a set of linear equations which expresses each receptor concentration of a chemical species as a linear sum of products of source profile species and source contribution. Exact knowledge of dispersion factor of emissions is not necessary in receptor models.

Geometric mean and standard deviation values of chemical parameters have been utilized for the concentration and uncertainties of corresponding species of specific site for development of source/receptor profiles. All prepared source and receptor profiles has been introduced in CMB model using an INFRA control file to execute source apportionment program (Watson et al 1997 and 1998). Results of CMB execution have been presented in Figs. 4, 5 and 6.

\section{Results and discussion}

\subsection{Annual flux and rate of dust fallout}

The total annual flux of airborne dust particulate has been calculated on the basis of month wise measurements of dust fall rate at different sources and receptor during February 2007-January 2009. All the sites have shown thousand times

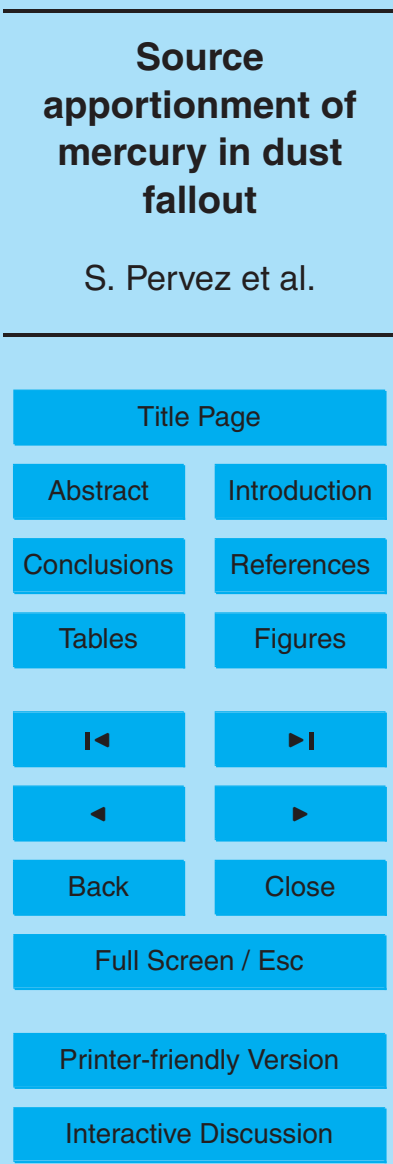

21922 
higher annual dust fall rate compared to prescribed standard of $0.01 \mathrm{mt} \mathrm{km}^{-2} \mathrm{month}^{-1}$ (Ferrari, 2000). The monthly dust fall rate were found to be in the range 67.71-391.01 $\mathrm{mt} \mathrm{km}^{-2} \mathrm{month}^{-1}$ for all six source sites and the receptor site has shown the range $51.78-119.64 \mathrm{mt} \mathrm{km}^{-2} \mathrm{month}^{-1}$ at ambient-outdoor level, $61.56-$ $5 \quad 143.56 \mathrm{mt} \mathrm{km}^{-2}$ month $^{-1}$ at outdoor-street and $12.34-18.92 \mathrm{mt} \mathrm{km}^{-2} \mathrm{month}^{-1}$ in houseindoors of residential area during the sampling period of 24 month. The lowest rate of dust fall in source sites was found at construction (S-4) in summer and the highest at Siltara industrial area (S-1) in spring and at receptor area (Birgaon) (R-1), the lowest rate found in post-rainy and the highest in winter at ambient-outdoor level. In street-outdoor level, lowest rate was found in post-rainy and the highest in winter season. Indoor-house has shown lowest dust fall in summer and the highest winter season. The geometric mean of dust fallout rate $\left(\mathrm{mt} \mathrm{km}^{-2} \mathrm{month}^{-1}\right)$ of 24 sampling months at different sampling sites were found tobe: $181.19 \pm 77.97$ (S-1), $217.43 \pm 24.41$ (S-2), $141.44 \pm 18.31$ (S-3), $87.85 \pm 25.49$ (S-4) and for receptor site (R-1), ambient15 outdoor level have shown $77.59 \pm 25.49$, street-outdoor $84.29 \pm 22.35$ and house-indoor 14.31 22.39. On the basis of monthwise dust fall rate, the highest total flux was observed to be measured at S-2 with an amount of $2624.78 \mathrm{mt} \mathrm{km}^{-2} \mathrm{yr}^{-1}$. The values of annual flux in the other sources, viz.S-1, S-3 and S-4 were 2313.91, 1709.1 and $1070.29 \mathrm{mt} \mathrm{km}^{-2} \mathrm{yr}^{-1}$, respectively. Linear regression analyses have shown that re20 ceptor site (Birgaon) is best correlated with Road dust fall (S-4) compared to other sources at ambient, street and indoor level (Fig. 2).

\subsection{Mercury levels in airborne dust fallout}

The analyses on month wise and site wise, mercury concentration in $\mathrm{mt} \mathrm{km}^{-2} \mathrm{~m}^{-1}$ has been calculated in $\mathrm{mt} \mathrm{km}^{-2} \mathrm{~m}^{-1}$ and annual site wise flux of $\mathrm{Hg}$ in $\mathrm{mt} \mathrm{km}^{-2} \mathrm{yr}^{-1}$ at different sites for the whole study period have also been evaluated and presented in Table 2. Month wise variation of flux of mercury in the airborne dust fall $\left(\mathrm{mt} \mathrm{km}^{-2} \mathrm{~m}^{-1}\right)$ for 24 sampling months at different sampling sites were observed to
ACPD

\section{Source \\ apportionment of \\ mercury in dust fallout}

S. Pervez et al.

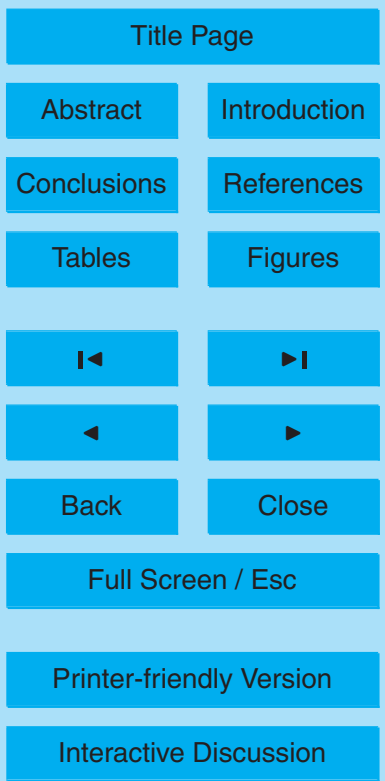


be in the range: $0.0017 \pm 0.0012$ in $S-1,0.0041 \pm 0.0037$ in S-2, $0.004 \pm 0.0038$ in S-3, $0.003 \pm 0.002$ in S-4, $0.0012 \pm 0.0005$ in S-5 and $0.0014 \pm 0.0011$ in S-6. For receptor site, the mercury concentrations have been found as: $0.0641 \pm 0.033$ at ambientoutdoor level, $0.0309 \pm 0.0324$ at street-outdoor, and $0.0342 \pm 0.0284$ at house-indoor

5 levels. The concentration of mercury at S-1 (Siltara industrial area) ranges between $0.0009-0.01 \mathrm{mt} \mathrm{km}^{-2} \mathrm{~m}^{-1}$ and at S-2 (Urla industrial area) it ranges between 0.001 $0.0104 \mathrm{mt} \mathrm{km}^{-2} \mathrm{~m}^{-1}$ dust falls. These are higher than the $\mathrm{Hg}$ concentrations found in other sources viz. S-3, S-4, S-5 and S-6. The Hg concentrations for other sources were in the range $0.0009-0.004 \mathrm{mt} \mathrm{km}^{-2} \mathrm{~m}^{-1}$ at S-3, $0.0009-0.002 \mathrm{mt} \mathrm{km}^{-2} \mathrm{~m}^{-1}$ at S$104,0.001-0.004 \mathrm{mt} \mathrm{km}^{-2} \mathrm{~m}^{-1}$ at S-5 and $0.001-0.006 \mathrm{mt} \mathrm{km}^{-2} \mathrm{~m}^{-1}$ at S-6 of dust matrix. Simultaneously, residential receptor have shown reception of $0.0414-0.0957$ at ambient level, $0.01-0.102$ at street and $0.019-0.082 \mathrm{mt} \mathrm{km}^{-2} \mathrm{~m}^{-1} \mathrm{Hg}$ at house indoor level in dust fall. Due to the maximum precipitation of airborne particulates, as well as highest concentration of $\mathrm{Hg}$ in industrial areas, the flux of $\mathrm{Hg}$ is also maximum in ambient-outdoor level. The next highest flux of dust fall-Hg has been found at heavy traffic-outdoors. House- indoors of R-1 has shown the least quantum of $\mathrm{Hg}$.

\subsection{Source apportionment studies}

\subsubsection{Preliminary assessment using regression analysis}

Dust fallout measurements of selected sources [Industrial complex, SIltara (S-1), Industrial complex, Urla (S-2), paved road (S-3) and Construction activities (S-5)] have been linearly regressed with measurements at classified atmospheric levels of defined receptor ( $R-1)$ to assess possible contribution effect on receptor site (Fig. 3). The intercept and slope values have been utilized to assess contribution effect of identified sources on receptor site (Geller et al., 2002; USEPA, 2003). It has been observed that industrial source S-1 and construction activities (S-5) have shown significant contribution. S-1 has shown about $39.29 \%$ contribution in dust fall while construction activities have shown $90 \%$ contribution effect in higher dust fall at ambient-outdoor level of R-1.

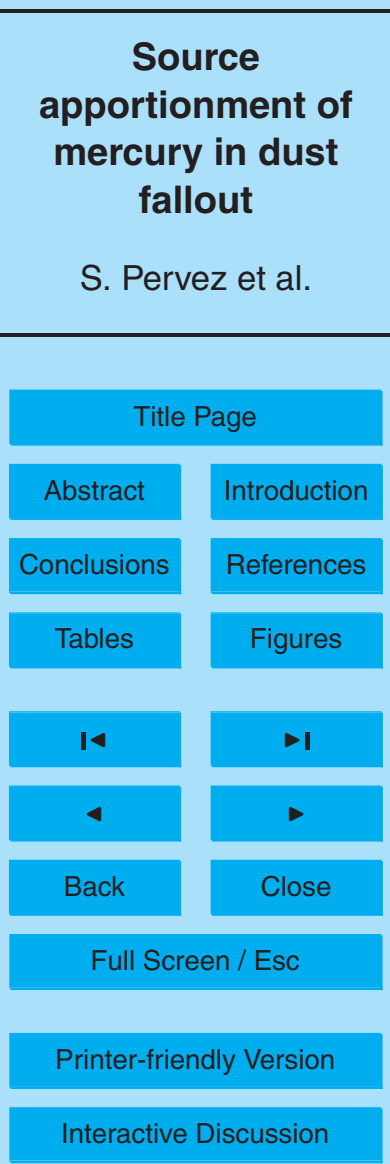


Other two sources (S-2 and S-3) have not shown any contribution in dust fall of ambient level. In case of street-outdoor level, industrial location of Siltara (S-1) have shown 17\% contribution effect, while other sources have not shown significant contribution. Paved road have shown major contribution in dust fall of local Street-outdoor of R-1. As far 5 as house-indoor levels is concern, paved road (S-3) and construction activities (S-5) have shown significant contribution effect of $90 \%$ and $62 \%$, respectively. Overall variation in source contribution effect on dust fallout measurements across the classified atmospheric levels at defined residential receptor has been observed.

\subsubsection{Source signatures of dust fallout and mercury content using receptor model}

Chemical compositional profile of identified six sources including soils of the study region has been developed using annual mean and standard deviation of measured 25 chemical constituents. The logarithmic chemical profiles of selected sources (S-1 to S-6) using statistical boxplots have been presented in Fig. 4. The source composition profiles of four sources and three atmospheric levels of defined receptor have been utilized for source apportionment of dust fallout and its mercury content at Birgaon residential outdoor (R-1). Besides, chemical profiles of vehicle exhaust (S-4) and local soils (S-6) have also been prepared and used for source apportionment modeling. Output of CMB8 with good fit parameters has been presented in Table 3. Multiple 20 source contribution has been observed with dominance of paved road in dust fall at all classified atmospheric levels of defined receptor. Re-suspension of poor quality paved road-dust has suppressed the soil dust contribution upto a large extent. Lower contribution of Urla Industrial source compared to Siltara Industrial source has been observed and variation in contribution could be assessed using wind channels of the study region. In contrast to international scenario, vehicle exhaust has shown lower contribution due to predominance of paved road dust source. In case of dust fall of ambient level, S-1 and S-5 have shown similar pattern of contribution, while in case of house-indoors, construction activities have not shown significant contribution.

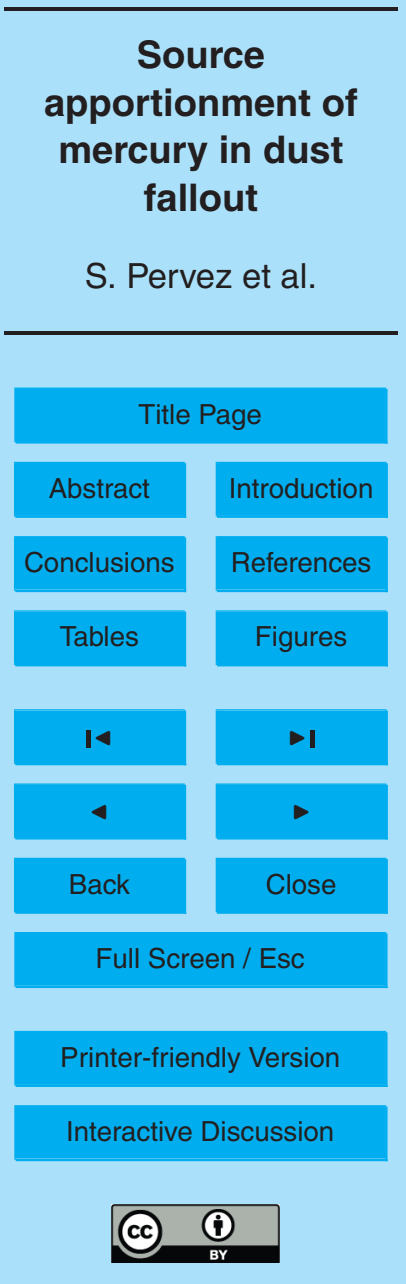


The results of source apportionment of mercury content of dust fallout have shown that construction activities was came out as major contributor with $30 \%$ with soils of $32 \%$. It has been reported earlier that cemetitious material has contain $0.02 \mathrm{~g}$ of mercury (ACC, 2007) and Airey (1997) has reported that mercury content has been found 5 in the range of $0.03-0.46 \mathrm{ppm}$ in ingredients of cement material. Vehicle exhaust and industrial location of Slltara have also shown significant contribution in mercury content of dust fall in all atmospheric levels of residential receptor (R-1). Overall, contrast result of source apportionment of dust fallout and mercury content of dust fall has been observed.

\section{Conclusion}

Profuse and highly skewed dust fallout at outdoor, street and indoor level of receptor (Birgaon) residential area has been observed. It has been observed that geometrical mean level of dust fallout at residential outdoor receptor is thousand times higher than maximum permissible limits $\left(0.01 \mathrm{mt} \mathrm{km}^{-2} \mathrm{~m}^{-1}\right)$ developed in Australia (Ferrari, 2000) 15 and also shown significant increase with a decade (Thakur and Deb, 1999). Dust fallout levels in Urla industrial area (S-2) has shown higher deviation pattern in annual geometrical mean compared to that in Siltara Industrial area (S-1) and attributed to the huge dust formation and emission from industrial processes. Paved road has also shown comparable levels with that measured in industrial sites due to higher degree of re-suspension of dusts formed during eruption of low quality paved road material. Annual mean of dust fallout measured at civil construction site has also shown thousand times higher levels compared to maximum permissible limits. The mercury concentration in dust fallout was found to be in the range $0.0009-0.01 \mathrm{mt} \mathrm{km}^{-2} \mathrm{~m}^{-1}$ of airborne dust fallout for all 6 source sites during the course of study. Thus, the annual flux of $\mathrm{Hg}$ 25 in the urban city is an alarming amount of $2.996 \mathrm{mt}$.

As far as source contribution assessment is concern, paved road (S-3) has shown major contribution in dust fall at all stages i.e. $37 \%$ at ambient, $60 \%$ street and $34 \%$

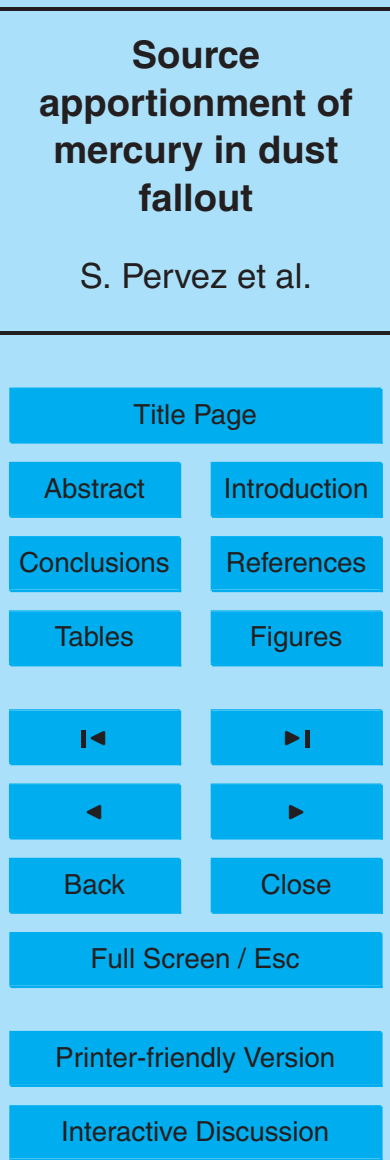

Interactive Discussion 
indoor level of R-1 (Birgaon residential area). Siltara industrial area (S-1) has shown significant contribution at all stages than Urla industrial area (S-2). Mercury source apportionment values have shown different source contribution at different level. Soil (S-6) have shown major contribution (32\%) at ambient level, Siltara industrial area 5 (S-1) have expressed major contribution (47\%) in street dust fallout and paved road (S-3) have given major contribution (44\%) in indoor dust fallout. Siltara industrial area has shown significant contribution at all levels compared to Urla industrial area and all other sources. Anthropogenic activities, wind velocity and wind directions have played the major role in higher contribution factor of source emitted dust fallout and mercury in selected residential receptor.

Acknowledgements. One of the authors (GB) is grateful to Pt. Ravishankar Shukla University, Raipur for providing laboratory and library facilities.

\section{References}

ACC (Associated Cement Companies), Mumbai: Sustainable Development Report 2007, 2007.

Adachi K. and Tainosho Y.: Characterization of heavy metal particles embedded in tire dust, Environ. Int., 30, 1009-1017, 2004.

Airey, D.: Contributions from Coal and Industrial Materials to Mercury in Air, Rainwater and Snow, J. Geochem. Exp., 58 (2-3), 223-229, 1997.

Arslan, H.: Heavy metals in street dust in Bursa, Turkey, J. Trace Micro. Tech., 19 (3), 439-445, 2001.

Barceloux, D. G.: Vanadium, Clinical Tox., 37 (2), 265-278, 1999.

Bushey, J. T., Driscoll, C. T., Mitchell, M. J., Selvendiran, P., and Motesdeoca, M. R..: Mercury transport in response to storm events from a northern forest landscape, Hydrol. Proc., 22, 4813-4826, 2008.

Bohm, G. M. and Saldiva, H. N.: Urban Air Pollution and Health Effect: A Summary of Evidences Collected in SaoPaulo, BRAZIL, Iniciativa De Aire Limpio, School of Medicine, University of Sao Paulo, Brazil, 2000.

\section{Source \\ apportionment of \\ mercury in dust fallout}

S. Pervez et al.

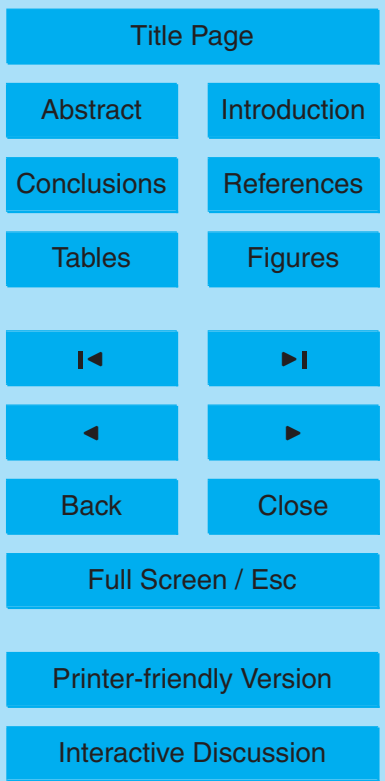


Davis, A. P., Shokouhian, M., and Ni, S.: Loading estimates of lead, copper, cadmium, and zinc in urban runoff from specific sources, Chemosphere, 44, 997-1009, 2001.

Dubey, N. and Pervez, S.: Investigation of Variation in Ambient $\mathrm{PM}_{10}$ Levels within an UrbanIndustrial Environment, Aer. Air Qual. Res., 8 (1), 54-64, 2008.

5 Dundar, M. S.: Vanadium concentrations in selected outdoor dust particles. Environmental Monitoring and Assessment, 123, 345-350, 2006.

Dundar, M. S. and Altundag, H.: Heavy metal determination of house dust in Adapazari, Turkey, after earthquake, Trace Elements and Electrolytes, 19 (2), 55-58, 2002.

Dundar, M. S. and Deryaoglu, N.: Heavy metal determinations in outdoor atmospheric dust depositions, Fresenius Environ. Bull., 14 (3), 185-188, 2005.

Dundar, M. S. and Pala, M. F.: Monitoring of lead, zinc, cadmium, nickel, chromium and copper in street dust samples in Adapazari, Turkey, after earthquake, Trace Elements and Electrolytes, 20 (2), 104-107, 2003.

EPMAP.: Mercury Atmospheric Processes: A Synthesis Report, EPRI/TR-104214; Expert Panel on Mercury Atmospheric Processes: Palo Alto, CA, USA, 1994.

Ferrari, L.: Dust nuisance: An Australian perspective, http://www.mfe.govt.nz/publications/air/ workshop-presentations/l-ferrari-dust-may00.pdf, 2000.

Gadkari, N. and Pervez, S.: Source apportionment of personal exposure of fine particulates among school communities in India, Environ. Monit. Assess., 142 (1-3), 227-241, 2008.

Gadkari, N. and Pervez, S.: Source investigation of personal particulates in relation to identify major routes of exposure among urban residentials, Atmos. Environ., 41, 7951-7963, 2007.

Keeler, G. J., Landis, M. S., Noris, G. A., Christianson, E. M., and Dvonch, J. T.: Source of mercury wet deposition in Eastern Ohio, USA, Environ. Sci. Technol., 40 (19), 58744-5881, 2006.

Gilbert, R. O.: Statistical methods for environmental pollution monitoring, John Wiley Publication, New York, USA, 1987.

Goel, P. K. and Trivedi, R. K.: An introduction to air pollution, Techno Science Publications, Jaipur, India, 1998.

ISWS: National Atmospheric Deposition Program 2002 Annual Summary. NADP Data Report 2003-01. Illinois State Water Survey. Champaign, IL, USA, 2003.

Katz, M.: Methods of air sampling and analysis, American Public Health Association (APHA), Interdisciplinary Book and Periodicals, Washington DC, USA, 1977.

Keeler, G., Glinsorn, G., and Pirrone, N.: Particulate mercury in the atmosphere: its signifi-

\section{Source \\ apportionment of \\ mercury in dust fallout}

S. Pervez et al.

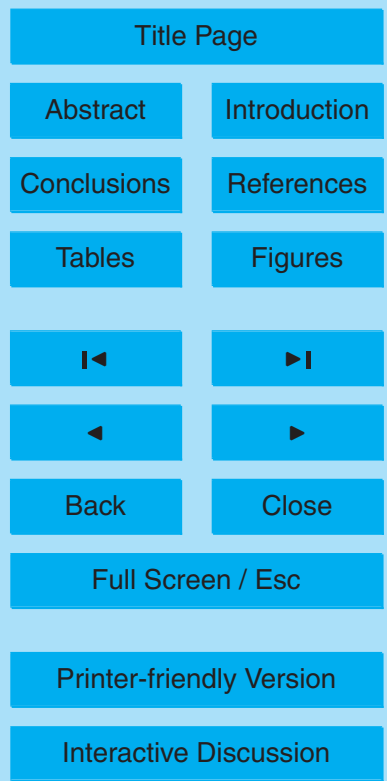


cance, transport, transformation and sources, Water Air Soil Pollut., 80, 159-168, 1985.

Landis, M. S., Keeler G. J., Al-Wali, K. I., and Stevens, R. K.: Divalent inorganic reactive gaseous mercury emissions from a mercury cell chlor-alkali plant and its impact on nearfield atmospheric dry deposition, Atmos. Environ., 38, 613-622, 2004.

5 Montaser, A. and Golightiy, D. W.: Inductive Coupled Plasma in Analytical Atomic Spectrometry, 2nd Edn, VCH Publication, New York, USA, 1987.

Mustard, M. H., Ellis, S. R., and Gibbs, J. W.: Runoff Characteristics and Washoff Loads from Rainfall-Simulation Experiments on a Street Surface and a Native Pasture in the Denver Metropolitan Area, Colorado, US Geological Survey, Open File Report 84-820, 1985.

10 Nriagu, J.: Global metal pollution: poisoning the biosphere, Environment, 32, 28-32, 1990.

Pitt, R. E.: Demonstration of nonpoint pollution abatement through improved street cleaning practices. EPA-600/2-79-161, Environmental Protection Agency, Cincinnati, OH, USA, 1979.

Pitt, R. E. and Amy, G.: Toxic materials analysis of street surface contaminants. EPA-R2-73283, Environmental Protection Agency, Washington DC, USA, 1973.

Quraishi, Y. F. and Pandey, G. S.: Exposure of steel plant related dusts in domestic environments in Bhilai residential areas, Indian J. Environ. Protect., 13 (8), 580-583, 1993.

Quraishi, Y. F. and Pandey, G. S.: Bronchial contamination with toxic metals in mineral based industrial areas of India, Environmental Geochemistry and Health, 17, 25-28, 1995.

Rogge, W. F., Hildemann, L. M., Mazurek, M. A., Cass, G. R., and Simoneit, B. R.: Sources of fine organic aerosol: 3. Road dust, tire debris, and organometallic brake lining dust: roads as sources and sinks. Environmental Science and Technology, 27, 1892-1904, 1993.

Roosli, M.: Spatial variability of air pollutants in the Basel area and carcinogenic and noncarcenogenic health risk. Ph.D. Thesis, University of Basel, Basel, Switzerland, 2001.

Sartor, J. D. and Boyd, G. B.: Water Pollution Aspects of Street Surface Contaminants. EPAR2-72-081. Environmental Protection Agency. Washington, 1972.

Sax, I. N. and Lewis, R. J.: Dangerous properties of industrial materials, 7th Edn., Vol-I, Van Nostrand Publication, New York, USA, 1984.

Saxena, D. K., Singh, S., and Srivastava, K.: Atmospheric heavy metal deposition in Garhwali hill area (India): estimation based on native moss analysis, Aerosol Air Qual.Res., 8 (1), 94-111, 2008.

Schroder, L. J. and Hedley, A. G.: Variation in Precipitation Quality during a 40-hour Snowstorm in an Urban Environment, Denver, CO, Intern. J. Environ. Studies, 28, 131-138, 1986.

Schroder, L. J., Brooks, M. H., Garbarino, J. R., and Willoughby, T. C.: The Influence of an

\section{Source \\ apportionment of \\ mercury in dust fallout}

S. Pervez et al.

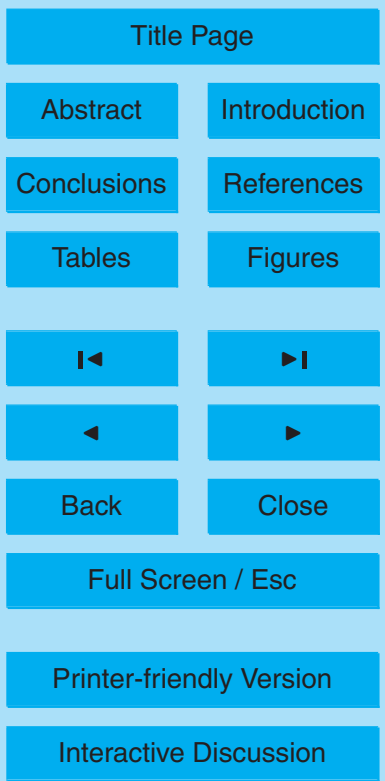


Urban Environment in the Chemical Composition of Precipitation, Chemical Quality of Water and the Hydrologic Cycle, Lewis Publishers, Chelsea, MI, USA, 1987.

Sharma, R. K. and Pervez, S.: Enrichment and exposure of particulate lead in a traffic environment in India, Environ. Geochem. Health, 25, 297-306, 2003.

5 Sharma, R. K. and Pervez, S.: A case study of spatial variation and enrichment of selected elements in ambient particulate matter around a large coal-fired power station in central India, Environ. Geochem. Health, 26 (3-4), 373-381, 2004.

Sharma, R. K. and Pervez, S.: Toxic metal status in human blood and breast milk samples in an integrated steel plant environment in central India, Environ. Geochem. Health, 27, 39-45, 2005.

Smolders, E. and Degryse, F.: Fate and effect of zinc from tire debris in soil, Environ. Sci. Technol., 36, 3706-3710, 2002.

Thakur, M. and Deb, M. K.: Lead levels in the airborne dusts particulates of an urban city of central India. Environmental Monitoring and Assessment, 62: 305-316, 1999.

15 Turkoglu, O., Saracoglu, S., and Soylak, M.: Trace metal levels in soil samples from crossroads in Kayseri-Ankara motorway, Trace Elements and Electrolytes, 20 (4), 225-229, 2003.

Tuzen, M.: Investigation of heavy metal levels in street dust samples in Tokat, Turkey, J. Trace and Microprobe Techniques 21 (3), 513-521, 2003.

USEPA: Fourth External Review Draft of Air Quality Criteria for Particulate Matter (June 2003). EPA/400/3-91/003Ad, United States Environmental Protection Agency, research triangle park A.C, 2003.

Watson, J. G., Robinson, N. F., Lewis, C., and Coulter, T.: Chemical mass balance receptor model version 8 (CMB8): Users manual. Document number 1808-1D1, Desert Research Institute, US environment protection agency (USEPA), 1997.

Watson, J. G., Robinson, N. F., Pujita, E. M., Chow, J. C., Pace, D. G., Lewis, C., and Counter, T.: CMB8 application and validation protocol for $\mathrm{PM}_{2.5}$ and VOCs. Document number 1808-2 D1, Desert Research Institute, US environment protection agency (USEPA), 1998.

Wieringa, M. H., Weyler, J. J., Van Bastelaer,, F. J., Nelen V. J., Van Sprundel, M. P., and Vermeire, P. A.: Higher asthma occurrence in an urban than a suburban area: role of house dust mite skin allergy, European Respiratory Journal, 10, 1460-1466, 1997.

\section{Source \\ apportionment of \\ mercury in dust fallout}

S. Pervez et al.

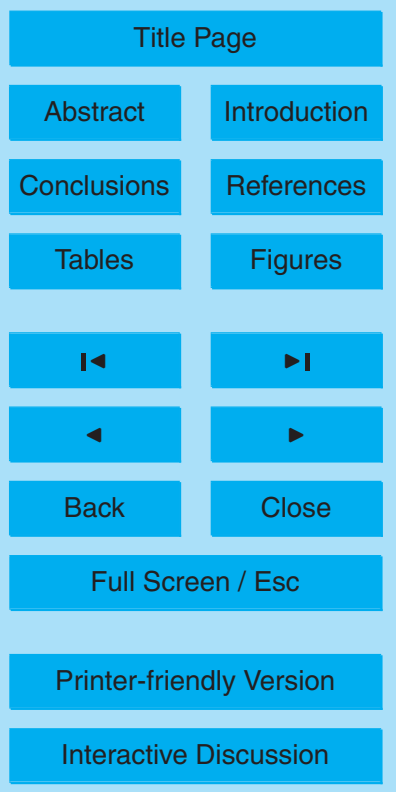




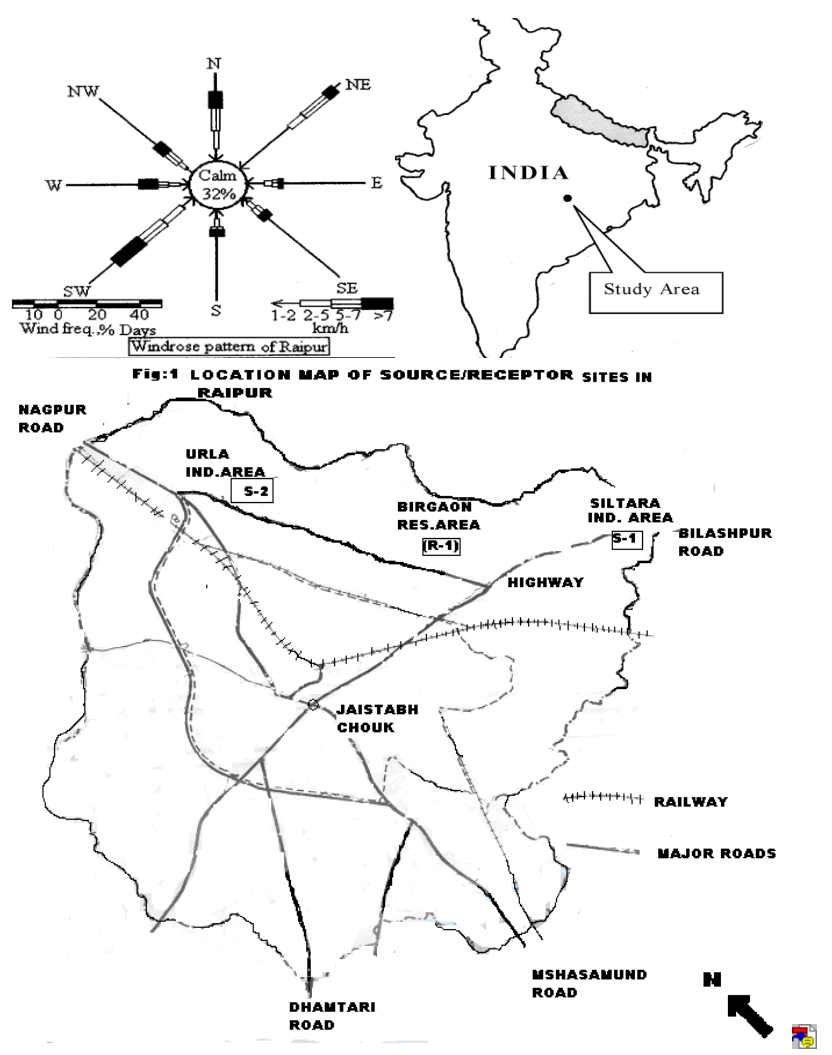

9, 21915-21940, 2009

\section{Source \\ apportionment of \\ mercury in dust \\ fallout}

S. Pervez et al.

Title Page

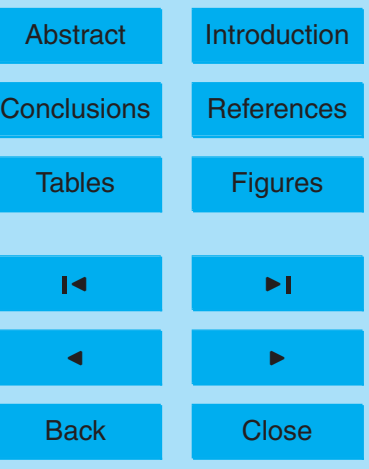

Full Screen / Esc

Fig. 1. Local map of source and receptor sites in Raipur City along with annual windrose of the region.

Printer-friendly Version

Interactive Discussion 


\section{RAIPUR}

1-2 WIND CHANNEL'S

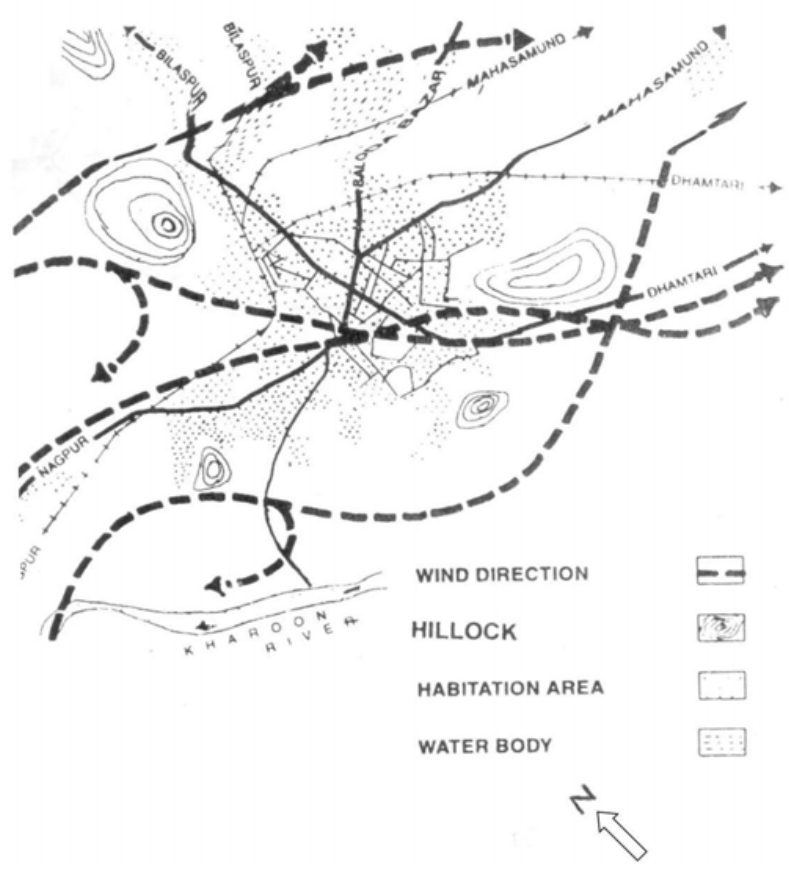

Fig. 2. Wind channels over the Raipur Region, India during sampling year.
9, 21915-21940, 2009

\section{Source}

apportionment of

mercury in dust

fallout

S. Pervez et al.

Title Page

Abstract

Introduction

Conclusions

References

Tables

Figures

14

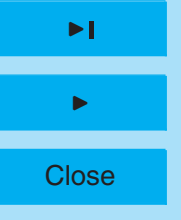

Back

Full Screen / Esc

Printer-friendly Version

Interactive Discussion 


\section{ACPD}

9, 21915-21940, 2009
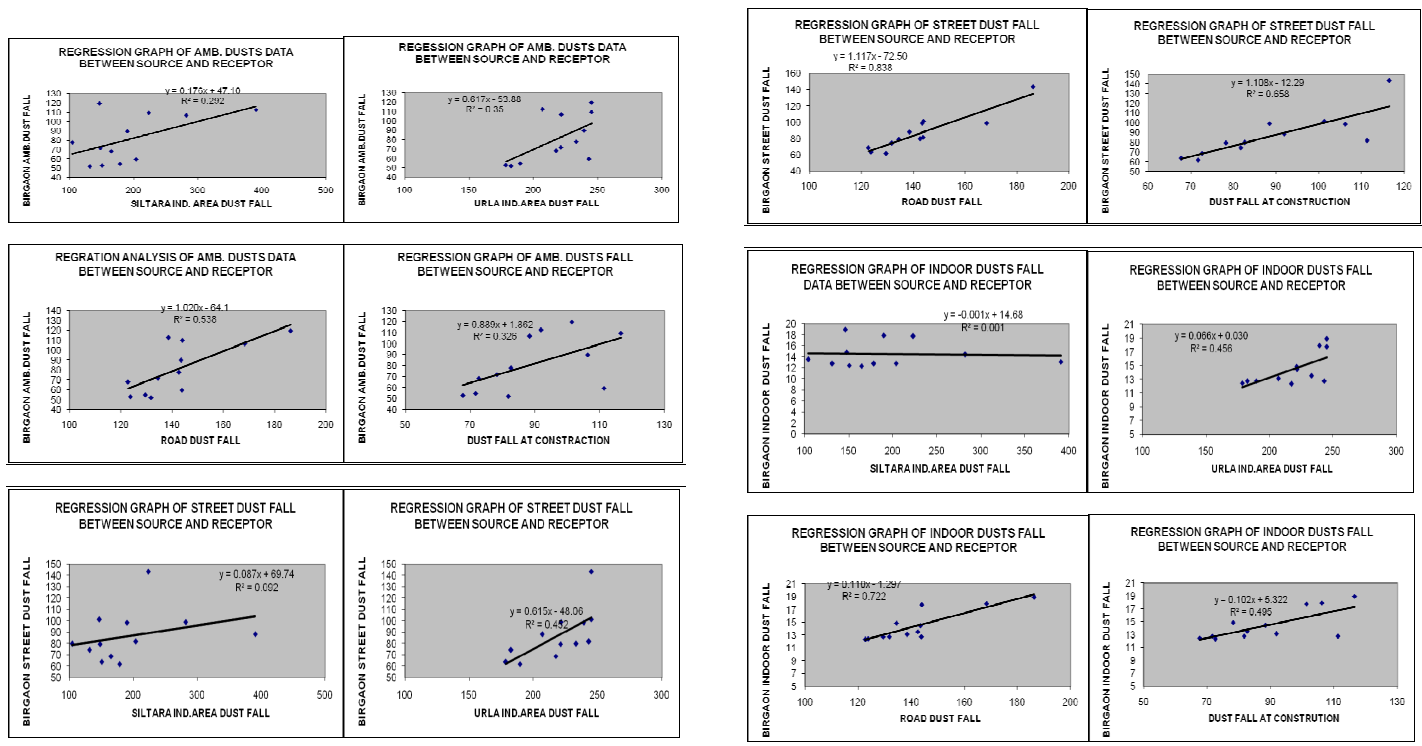

Fig. 3. Regression analysis between selected dust fallout receptors and dust fallout at identified selected source sites in urban-industrial environment of India.

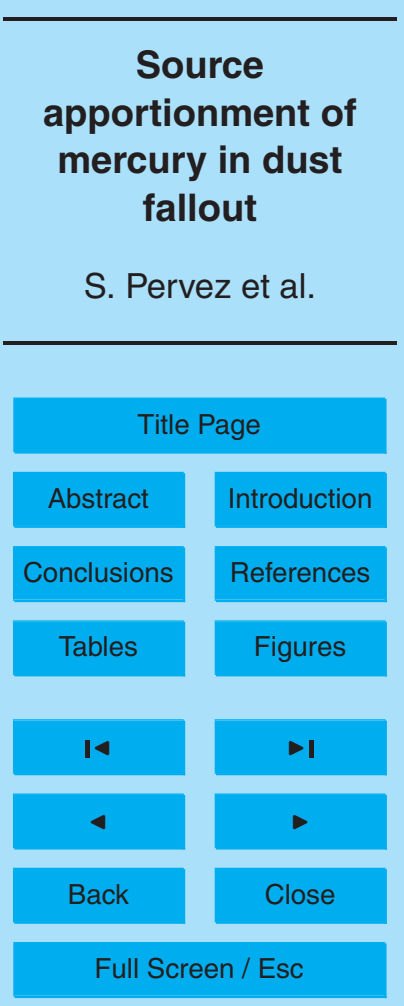

Printer-friendly Version

Interactive Discussion 


\section{ACPD}

9, 21915-21940, 2009
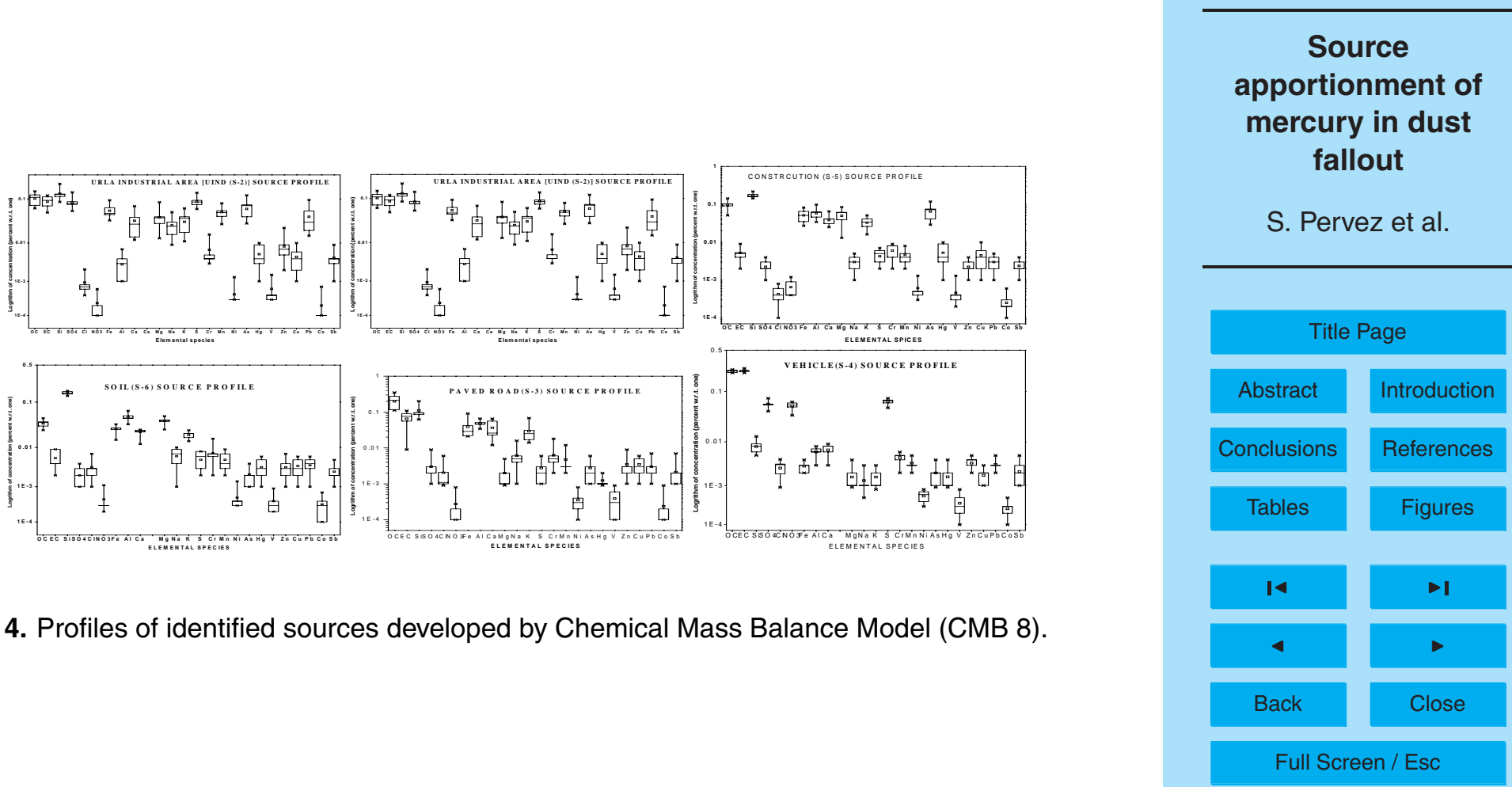

Printer-friendly Version

Fig. 4. Profiles of identified sources developed by Chemical Mass Balance Model (CMB 8).

Interactive Discussion 


\section{ACPD}

9, 21915-21940, 2009

\section{SOURCE CONTRIBUTION OF AMB.DUST} FALLOUT
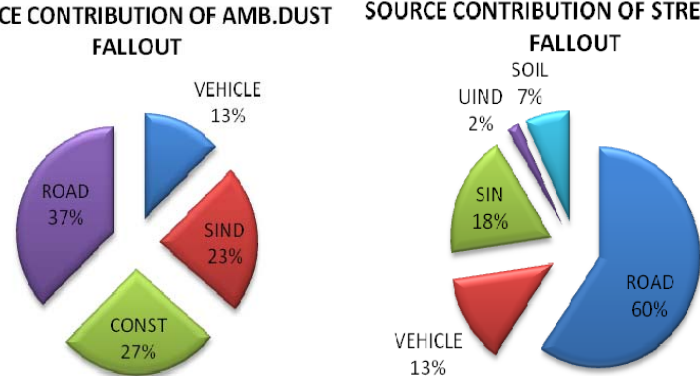

SOURCE CONTRIBUTION OF INDOOR DUST FALL

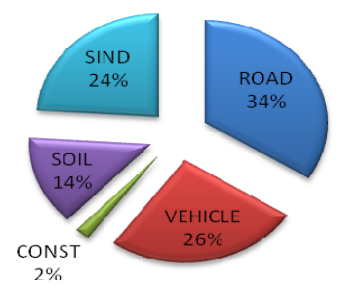

Fig. 5. Relative source contribution estimates of dust fallout at selected classified atmospheric levels in residential zone of urban-industrial environment.

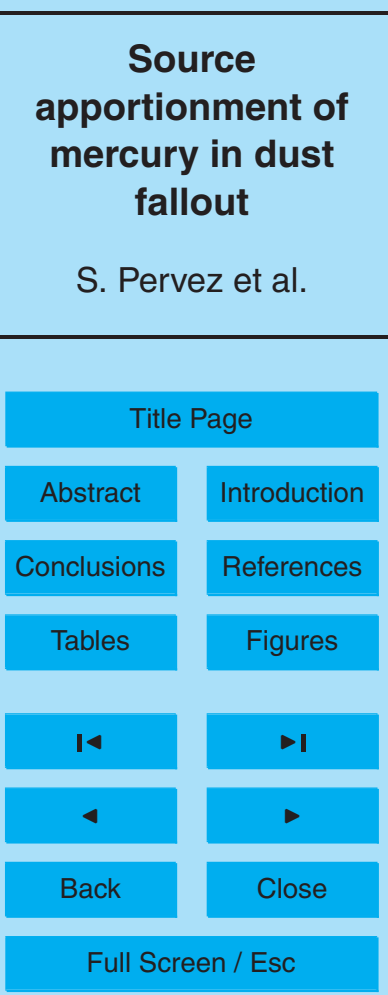

Printer-friendly Version

Interactive Discussion 


\section{ACPD}

9, 21915-21940, 2009

\section{SOURCE CONTRIBUTION OF AMBIENT Hg}

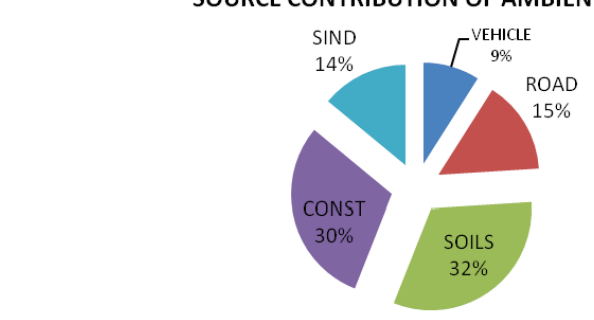

Source

\section{apportionment of \\ mercury in dust \\ fallout}

SOURCE CONTRIBUTION OF HG AT STREET

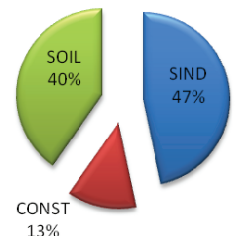

SOURCE CONTRIBUTION OF HG IN INDOOR

VEHICLE

$28 \%$

\%

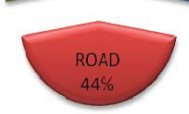

S. Pervez et al.

Title Page

Abstract

Conclusions

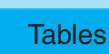

Tables
14

4

Back

Full Screen / Esc

Printer-friendly Version

Interactive Discussion

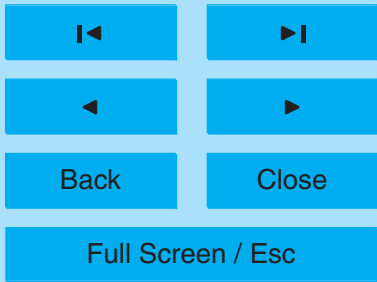

Fig. 6. Relative source contribution estimates of particulate mercury at selected classified atmospheric levels in residential zone of urban-industrial environment. 


\section{ACPD}

Table 1. Identification and grouping of defined sources and receptor in the study area.

\begin{tabular}{|c|c|c|c|c|c|}
\hline S.No. & $\begin{array}{l}\text { Name of } \\
\text { Source/receptor }\end{array}$ & Type & $\begin{array}{l}\text { Classification of moni- } \\
\text { toring level }\end{array}$ & Site characteristics & $\begin{array}{l}\text { Sampling } \\
\text { Frequency }\end{array}$ \\
\hline \multicolumn{6}{|c|}{ Source sites } \\
\hline S-1 & Siltara industrial area & $\begin{array}{l}\text { Stationary } \\
\text { point }\end{array}$ & Ambient-outdoor & $\begin{array}{l}\text { Most of the industries } \\
\text { are: casting, sponge } \\
\text { iron, steel foundries. }\end{array}$ & \multirow[t]{6}{*}{$\begin{array}{l}24 \text { samples } \\
\text { throughout the } \\
\text { sampling of two } \\
\text { year (One in each } \\
\text { month) }\end{array}$} \\
\hline S-2 & Urla Industrial, area & $\begin{array}{l}\text { Stationary } \\
\text { point }\end{array}$ & Ambient-outdoor & $\begin{array}{l}\text { Most of the industries } \\
\text { are: casting, chemical, } \\
\text { oil production, glass } \\
\text { and plastics. }\end{array}$ & \\
\hline S-3 & Paved road & Line & outdoor & $\begin{array}{l}\text { Re-suspended dusts of } \\
\text { road side runoff mea- } \\
\text { sured at } 3 \mathrm{ft} \text { height }\end{array}$ & \\
\hline S-4 & Automobile & Point & Emission outlet & $\begin{array}{l}\text { Mixed dust fraction } \\
\text { emitted from silencer } \\
\text { of truck, cars and two } \\
\text { wheelers }\end{array}$ & \\
\hline S-5 & Civil construction & Area & Ambient-outdoor & $\begin{array}{l}\text { Dusts emitted from } \\
\text { handling of raw ma- } \\
\text { terials used in civil } \\
\text { construction site }\end{array}$ & \\
\hline S-6 & Local soils & Area source & - & $\begin{array}{l}\text { Re-suspension of soil } \\
\text { dusts }\end{array}$ & \\
\hline \multicolumn{6}{|c|}{ Receptor sites } \\
\hline $\begin{array}{l}\text { R-1 } \\
\text { R-2 } \\
\text { R-3 }\end{array}$ & Birgaon, Raipur & $\begin{array}{l}\text { Residential } \\
\text { area }\end{array}$ & $\begin{array}{l}\text { Ambient-outdoor } \\
\text { House-Indoors } \\
\text { Local Street-Outdoors }\end{array}$ & $\begin{array}{l}\text { Residential area lo- } \\
\text { cated northeasterly } \\
\text { and downwind to } \\
\text { industrial complexes }\end{array}$ & $\begin{array}{l}24 \text { samples } \\
\text { throughout the } \\
\text { sampling of two } \\
\text { year (One in each } \\
\text { month) }\end{array}$ \\
\hline
\end{tabular}

Source

\section{apportionment of \\ mercury in dust \\ fallout}

S. Pervez et al.

Title Page

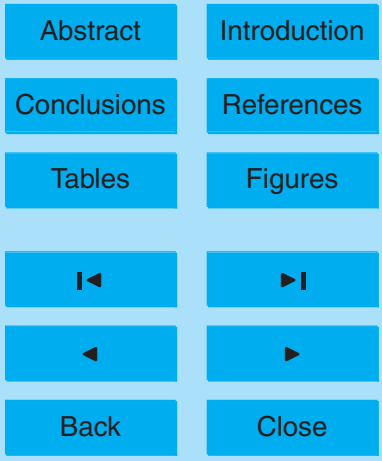

Full Screen / Esc

Printer-friendly Version

Interactive Discussion 


\section{ACPD}

9, 21915-21940, 2009

\section{Source \\ apportionment of \\ mercury in dust \\ fallout}

Table 2. Yearly average dust fallout $\left(\mathrm{mt} \mathrm{km}^{-2} \mathrm{~m}^{-1}\right)$ monitored in classified receptor and source

S. Pervez et al. sites.

\begin{tabular}{lll}
\hline \multicolumn{3}{c}{ Receptor sites } \\
\hline Ambient-outdoor & House indoors & Street outdoors \\
\hline $77.59 \pm 25.48$ & $14.31 \pm 2.38$ & $84.29 \pm 22.35$ \\
$(51.784-119.64)$ & $(12.342-18.923)$ & $(61.56-143.56)$ \\
$(0.064 \pm 0.033)^{*}$ & $(0.0342 \pm 0.0284)^{*}$ & $(0.0309 \pm 0.0324)^{*}$ \\
$(0.033-0.118)$ & $(0.018-0.089)$ & $(0.011-0.102)$ \\
\hline
\end{tabular}

Title Page

Abstract

Introduction

Conclusions

References

Tables

Figures

14

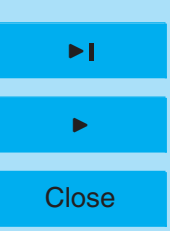

Back

Close

Full Screen / Esc

Printer-friendly Version

Interactive Discussion 


\section{ACPD}

9, 21915-21940, 2009

\section{Source \\ apportionment of \\ mercury in dust \\ fallout}

Table 2. Continued.

S. Pervez et al.

\begin{tabular}{llllll}
\hline \multicolumn{7}{c}{ Source sites } \\
\hline S-1 & S-2 & S-3 & S-4 & S-5 & S-6 \\
$181.18 \pm 77.97$ & $217.42 \pm 24.41$ & $141.43 \pm 18.32$ & ND & $87.84 \pm 16.36$ & ND \\
$(131.51-391.00)$ & $(178.54-245.29)$ & $(122.73-186.25)$ & $(0.027 \pm 0.002)^{*}$ & $(67.71-116.54)$ & $(0.0014 \pm 0.001)^{*}$ \\
$(0.0017 \pm 0.0012)^{*}$ & $(0.00399 \pm 0.0038)^{*}$ & $(0.0012 \pm 0.0005)^{*}$ & $(0.001-0.06)$ & $(0.0039 \pm 0.0038)^{*}$ & $(0.0009-0.004)$ \\
$(0.001-0.004)$ & $(0.001-0.01)$ & $(0.0009-0.002)$ & & $(0.001-0.01)$ & \\
\hline
\end{tabular}

* Values of annual average mercury concentration and its standard deviation.

Values in parenthesis are minimum and maximum levels throughout sampling period.

Abbreviation: $\mathrm{Mt}$ - metric tone, $\mathrm{m}$ - month, ND - Not measured.

Title Page

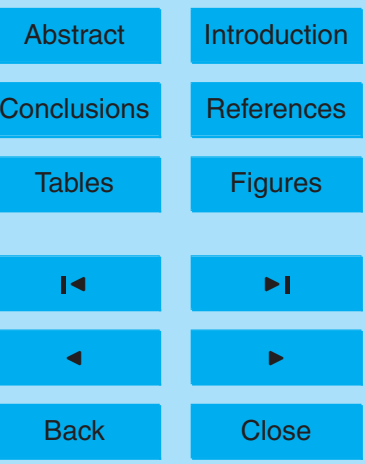

Full Screen / Esc

Printer-friendly Version

Interactive Discussion 


\section{ACPD}

9, 21915-21940, 2009

\begin{tabular}{l} 
Source \\
apportionment of \\
mercury in dust \\
fallout \\
S. Pervez et al. \\
\hline
\end{tabular}

Table 3. Good fit parameters of CMB execution output results for selected receptors.

\begin{tabular}{lllllllll}
\hline Receptors & $R^{2}$ & \multicolumn{1}{l}{ CHI } \\
SQUARE
\end{tabular}

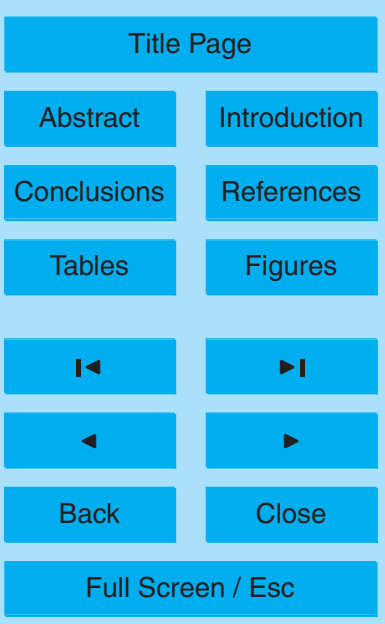

Printer-friendly Version

Interactive Discussion 